\title{
Evaluation of saturated hydraulic conductivity from soil properties in an Inceptisol using different land cover and depths
}

\author{
Tapan Kumar Kisku ${ }^{*}$, Ashim Datta ${ }^{2}$, Nirmalendu Basak $^{2}$, Sunil Mandi ${ }^{3}$, Sandip \\ Hembram $^{4}$, Ratneswar Roy ${ }^{1}$ \\ ${ }^{1}$ Department of Soil and Water Conservation, Bidhan Chandra Krishi Viswavidyalaya, Mohanpur, Nadia, West \\ Bengal-741 252, INDIA \\ ${ }^{2}$ Division of Soil and Crop Management, ICAR-Central Soil Salinity Research Institute, Karnal-132001 (Haryana), \\ INDIA \\ ${ }^{3}$ ICAR-Central Tobacco Research Institute, Regional Research Station, Dinhata, Cooch Behar-736135 (West \\ Bengal), INDIA \\ ${ }^{4}$ Department of Agricultural Chemistry and Soil Science, Bidhan Chandra Krishi Viswavidyalaya, Mohanpur, \\ Nadia, West Bengal-741252, INDIA \\ *Corresponding author. E-mail: tapan.kalyani@gmail.com
}

Received: September 15, 2016; Revised received: February 26, 2017; Accepted: July 25, 2017

\begin{abstract}
Three soil profiles from Regional Research Station of Bidhan Chandra Krishi Viswavidyalaya, Gayeshpur situated in New Alluvial zone of Nadia district, West Bengal were studied to assess the predictability of the hydraulic conductivity of the soil as influenced by different physical and chemical and properties of cultivated and forest land. The various statistical procedures were employed on the measured laboratory based data for comprehensive agreement of dependent hydraulic conductivity of soils as a model function of independent soil variables that is likely to be useful for different land cover systems. Soils are neutral in reaction, silty clay to silty clay loam in nature. Forest soil contained greater organic carbon $(\mathrm{OC})\left(5.9 \pm 0.16 \mathrm{~g} \mathrm{~kg}^{-1}\right)$ compared to cultivated soil $\left(4.4 \pm 0.34 \mathrm{~g} \mathrm{~kg}^{-1}\right)$. Jhau plantation recorded the highest value $\left(6.8 \mathrm{~g} \mathrm{~kg}^{-1}\right)$ of $\mathrm{OC}$ due to soil texture and cation exchange capacity (CEC). Soil hydraulic conductivity was greater in soil for cabbage and Sagun tree among the cultivated and forest soil studied with values 2.80 and $1.10 \mathrm{cmh}^{-1}$. Correlation study showed a positive and negative relation with hydraulic conductivity for sand $(r=0.68 ; P>0.05)$ and clay $(r=-0.71 ; \mathrm{P}>0.05)$ respectively. Further, principal component analysis concluded that addition of bulk density with clay and sand can predict the hydraulic conductivity for different land uses.
\end{abstract}

Keywords: Forest land, Hydraulic conductivity, Land cover, Principal component analysis

\section{INTRODUCTION}

Soil is dynamic in nature and prone to natural changes. Both direct and cyclic changes take place simultaneously in soil over time ranging from days to millennia. Impacts of human activity are super imposed on these natural changes and their significance should be evaluated in the light of natural changes. Assessment of the sensitivity of soil landscape to further changes should also consider natural variability in both space and time (Yuksek et al., 2010). Dynamics of soil moisture storage in the potential crop root zone is of primary importance to plant growth and agricultural production. Soil physical characteristics such as hydraulic conductivity and infiltration rate co-determined the magnitude of rate of water flow in the soil. Different land management practices like cultivation or tillage operation, cropping system, mulches and land-use-cover affects soil physical properties (Bezabih et al., 2016).

Particle size distribution of soils and sediments is also important to hydraulic properties because size distribution affect the movement and retention of water, consistency and tilth, and capacity to shrink and swell etc. (Assouline and Narkis, 2013). The hydraulic conductivity $(\mathrm{k})$ is the ease with which a soil conducts or transmits water through its pores. It is the proportionality constant in Darcy s law indicating the ability of the soil to transmit flowing liquid (water). The hydraulic conductivity of saturated soil is sometimes termed as permeability or saturated hydraulic conductivity which determines water availability for plants, nature of crops suitable to grow and the land capacity for groundwater recharge. The water permeability of the soil, to a large extent, determines how efficient an irrigation or drainage system functions. The hydraulic conductivity is not an exclusive property of the soil alone, since it depends upon the attributes of soil and the fluid together (Chaudhari et al., 2010). The soil characteristics, which affect the hydraulic conductivity, are the total porosity, the distribution of pore sizes and tortuosity, 
in short the pore geometry of the soil (Bandyopadhyay et al., 2011; Chaudhari et al., 2015).

Among various land -use-land cover systems, forest cover greatly influences infiltration rate and hydraulic conductivity of soils. The litter fall from the forest trees and its storage underneath the tree canopy improved the water retention of soil mainly by way of developing surface and sub-surface macro-porosity, reducing surface runoff and controlling soil erosion. Different species have differential effects on soil characteristics; however, there was an overall improvement of soil physical, chemical and biological environment (Newaj et al., 2007). The extent of leaching directly depends on the hydraulic properties of the plant growing media (soil or plant matrix). Leaching is substantially reduced when the hydraulic conductivity of the media is lower for a stabilised soil and substantially increases when the hydraulic conductivity is increased (Rao and Mathew, 1995). In fine grain soils, the hydraulic conductivity under saturated conditions is controlled by the microstructure of the soil matrix which in turn depends on the type of the fine materials (e.g., clay mineral) present in the soil, the composition of the exchangeable cations, and the electrolyte concentration in the pore water system (Ndiaye et al., 2007). It has long been recognized that hydraulic conductivity is related to the grain size distribution of granular porous media (Bardhan et al., 2016). Since hydraulic conductivity can vary, depending on many indices, it is difficult to treat all these parameters at the same time (Chaudhari et al., 2010).

It is now recognized that hydraulic characteristics can be obtained from direct and field measurements. However, these measurements are time consuming, cumbersome and costly. This has led to development of statistical methods for estimation of hydraulic conductivity from basic soil properties which may be either physical or chemical properties (e.g. percentage of clay, silt, sand and organic matter etc.) or the soil moisture characteristics and relates them to the hydraulic properties. In many cases the relationship so developed proved to be excellent for predicting hydraulic properties (ANOVA), coefficient of correlation (r) The objectives of this study were: i) to develop some models to predict the hydraulic conductivity of soils as modified by soil properties and land use systems. ii) To find out interrelationship of hydraulic conductivity with soil properties.

\section{MATERIALS AND METHODS}

The study area stretches in the Central Research Farm, Regional Research Station, Bidhan Chandra Krishi Viswavidyalaya, Gayeshpur, Nadia, West Bengal, India. The area falls under New Alluvial Zone and is located at $22^{0} 58^{\prime} \mathrm{N}$ latitude and $88^{\circ} 29^{\prime} \mathrm{E}$ longitude with an elevation of $9.75 \mathrm{~m}$ above mean sea level (msl). It includes portion of fertile land intensively

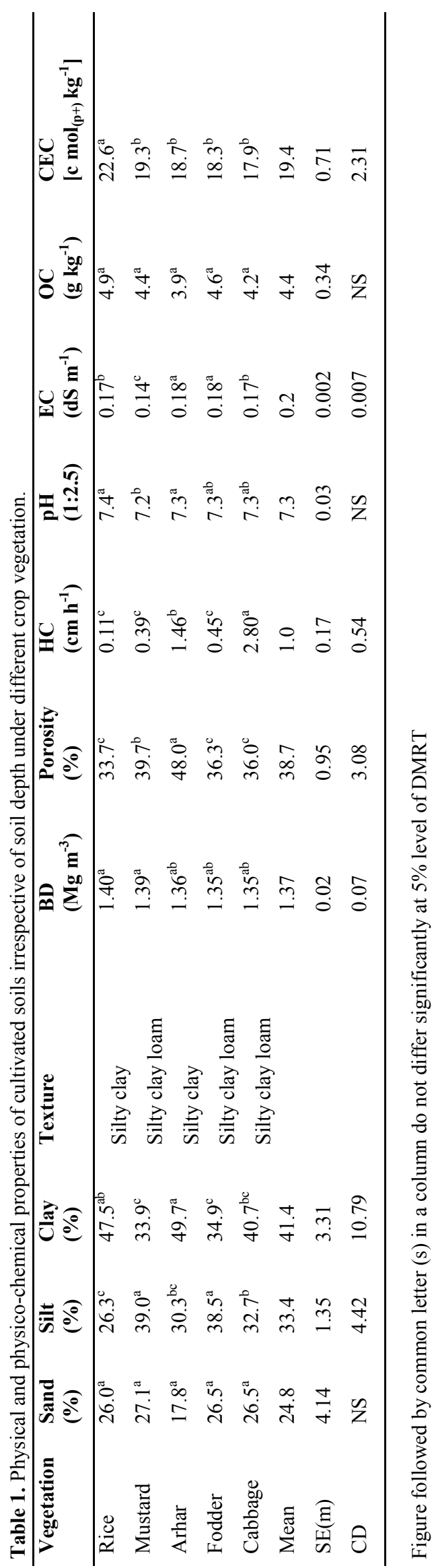


Tapan Kumar Kisku et al. / J. Appl. \& Nat. Sci. 9 (3): 1482 -1488 (2017)

Table 2. Physical and Physico-chemical properties of cultivated soils at varying depth irrespective of crop vegetation

\begin{tabular}{|c|c|c|c|c|c|c|c|c|c|c|c|}
\hline $\begin{array}{l}\text { Depth } \\
\text { (m) }\end{array}$ & $\begin{array}{c}\text { Sand } \\
(\%)\end{array}$ & $\begin{array}{l}\text { Silt } \\
(\%)\end{array}$ & $\begin{array}{l}\text { Clay } \\
(\%)\end{array}$ & Texture & $\begin{array}{c}\text { BD } \\
\left(\mathrm{Mg} \mathrm{m}^{-3}\right)\end{array}$ & $\begin{array}{c}\text { Porosity } \\
(\%)\end{array}$ & $\begin{array}{c}\mathrm{HC} \\
\left(\mathrm{cm} \mathrm{hr}^{-1}\right)\end{array}$ & $\begin{array}{c}\text { pH } \\
(1: 2.5)\end{array}$ & $\begin{array}{c}E C \\
\left(\mathrm{dS} \mathrm{m^{-1 }}\right) \\
\end{array}$ & $\begin{array}{c}\mathrm{OC} \\
\left(\mathrm{g} \mathrm{kg}^{-1}\right)\end{array}$ & $\begin{array}{c}\text { CEC } \\
{\left[\mathrm{c} \mathrm{mol} \mathbf{l}_{\left(\mathbf{p}^{+}\right)} \mathrm{kg}^{-1}\right]}\end{array}$ \\
\hline $0-0.15$ & 23.6 & 32.6 & 43.0 & Silty clay & 1.37 & 38.7 & 1.00 & 7.3 & 0.20 & 4.4 & 19.4 \\
\hline $0.15-0.3$ & 24.8 & 33.4 & 41.4 & Silty clay & 1.39 & 36.6 & 1.03 & 7.3 & 0.167 & 4.0 & 18.6 \\
\hline $0.3-0.45$ & 27.3 & 34.4 & 38.3 & Silty clay loam & 1.42 & 36.0 & 0.76 & 7.4 & 0.173 & 3.2 & 16.6 \\
\hline $\mathrm{SE}(\mathrm{m})$ & 3.21 & 1.05 & 2.56 & & 0.016 & 0.733 & 0.13 & 0.03 & 0.002 & 0.26 & 0.55 \\
\hline $\mathrm{CD}$ & NS & NS & NS & & 0.05 & 2.39 & 0.42 & 0.08 & 0.005 & 0.86 & 1.79 \\
\hline
\end{tabular}

cultivated, uncultivated, fallow land and a fraction of land under forest of different tree species. The climate of this area is sub tropical-sub humid. The annual rainfall received during the investigation period (20072008) was about $2414 \mathrm{~mm}$. The major portion (75$80 \%$ ) of which was being concentrated during the four monsoon months from June to September. The average temperature ranged from 25 to $36.5^{\circ} \mathrm{C}$ during summer and 10.0 to $25^{\circ} \mathrm{C}$ during winter. May is generally the hottest month of the year and December and January are the coldest months. The soil of the area is Gangetic alluvium in nature and shallow to medium in depth and belongs to fine loamy Fluventic Ustochrept. The tree species were Sissoo (Dalbergia sissoo), Segun (Tectona grandis), Jhau (Casuarina equisetifolia), Sirish (Samania saman) and Lambu (Dysoxylum binactatiferum) and the crop vegetation included rice, arhar, mustard, cabbage and fodder crops.

Collection of soil sample: Composite soil samples were collected randomly with the help of soil auger at depth of $0-0.15,0.15-0.30$ and $0.30-0.45 \mathrm{~m}$ from uncultivated, cultivated and forest lands, respectively and passed through a $2 \mathrm{~mm}$ opening sieve and kept in polythene container for analysis. Physico-chemical properties of the soil collected from different land uses were determined using standard methods of soil analysis: particle size analysis using the hydrometer method as described by Bouyoucos (1962) and bulk density as described by Blake and Hartge (1986), soil pH measured by glass electrode $\mathrm{pH}$ meter as described by Jackson (1973), cation exchange capacity (CEC) as described by Scollenberger and Simon (1982), soil or-

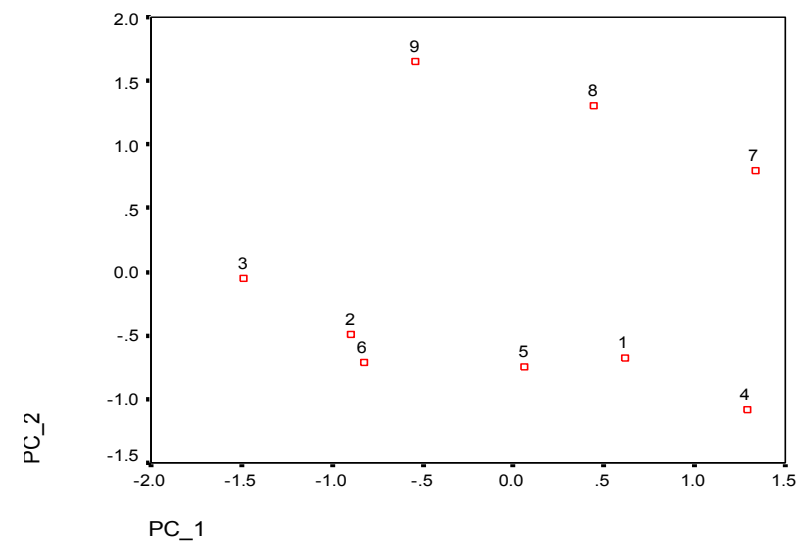

Fig. 1. Scatter diagram of different regression factor scores of all sequences for first two components due to PCA. ganic carbon (OC) using Walkley-Black method as described by Nelson and Sommers (1982), Electrical conductivity (EC) measured with the help of conductivity meter followed by Jackson (1973).

Specific procedure followed for the test is provided below

Saturated hydraulic conductivity: Constant head method was employed for determining the hydraulic conductivity of soil sample (Bouma et al., 1981). Air dry representative soil samples were passed through a $2 \mathrm{~mm}$ sieve and dumped in the soil container (Brass core) fitted with a filter paper in one motion. The cylinder containing the soil was dropped 20 times from a distance of $2.5 \mathrm{~cm}$ to facilitate the uniform filling and to avoid the trapping of air in the soil. The sample was placed to about two-third full inside the permeameter sample compartment. Out of two filter papers, one is placed at the top of the soil. A constant head device was maintained through overnight for saturation (connecting soil container by siphon tube to water supply) and a beaker placed under the outlet of the container. When the outflow became constant and measured against time. The hydraulic conductivity was calculated by the Darcy's Law (Bardhan et al., 2016):

$\mathrm{Ks}=\mathrm{Q} \Delta \mathrm{L} / \Delta \mathrm{H} \mathrm{A} \mathrm{T}$

Where, $\mathrm{Q}=$ Volume of water passing through the soil in time, $\mathrm{T}\left(\mathrm{cc} \mathrm{h}^{-1}\right)$

$A=$ Cross sectional area of the soil $\left(\mathrm{cm}^{2}\right)$

$\mathrm{L}=$ Soil height $(\mathrm{cm})$

$\mathrm{H}=$ Hydraulic head difference $(\mathrm{cm})$

$\mathrm{Ks}=$ Saturated hydraulic conductivity $\left(\mathrm{cm} \mathrm{h}^{-1}\right)$

Statistical analysis: The data obtained were statistically analysed by using the Duncan's Multiple Range Test (DMRT), principal component analysis (PCA) and analysis of variance (Gomez and Gomez, 1984).

\section{RESULTS AND DISCUSSION}

Physical properties of cultivated soils: Soils under arhar and rice were silty clay in texture with high clay content ( 49.7 and $47.5 \%$, respectively) but soils under mustard, fodder and cabbage were silty clay loam in texture with relatively higher amount of silt (39.0, 38.5 and $32.7 \%$ ) (Table 1). Marginally higher value of bulk density (BD) was recorded in soils under rice and mustard crop. The possible reason of higher BD in soils under rice and mustard might be due to relatively lower amount of silt (26.3\%) and clay (33.9\%) content in respected soils. Porosity of the soil was highest in 

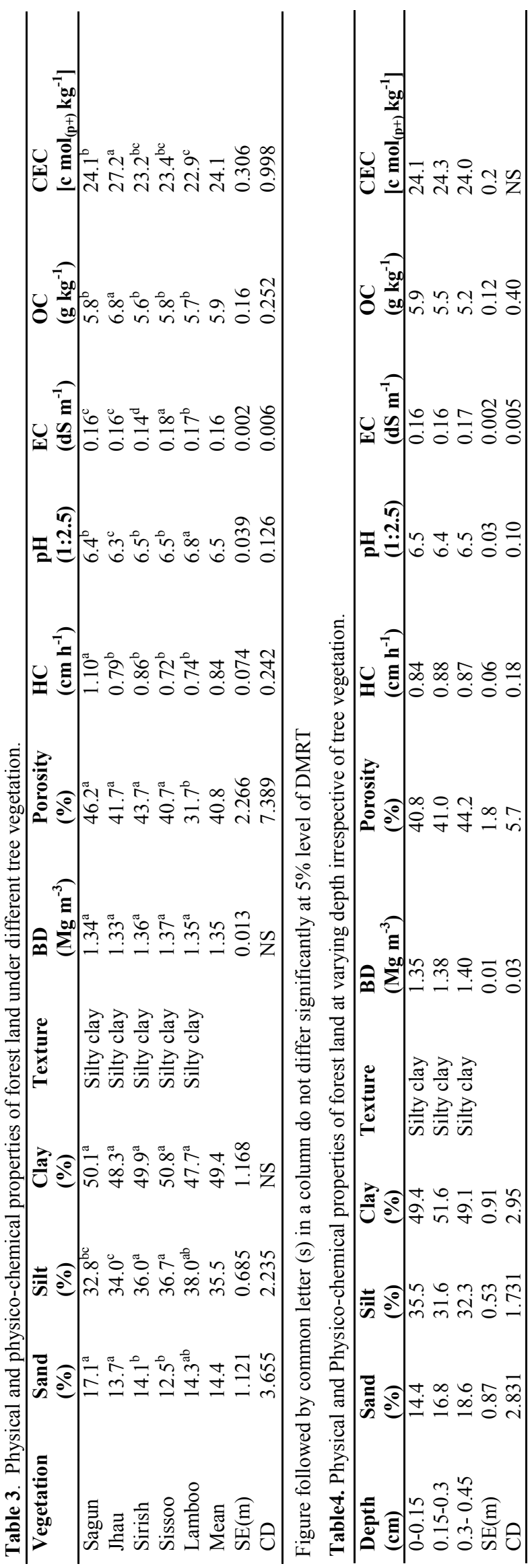

arhar $(48.0 \%)$ which might be due to improved soil structure resulting from production of leaf litter and increase in microbial properties which makes the soil more porous and voluminous (Bandyopadhyay et al., 2011). The saturated hydraulic conductivity (HC) of the experimental soils was highest in cabbage followed by arhar, fodder, mustard and rice with $2.80,1.46$, $0.45,0.39$ and $0.11 \mathrm{~cm} \mathrm{~h}^{-1}$, respectively. Rice cultivation caused lowering in the conductivity than other crop cultivations which might be due to destruction of soil aggregates by puddling and formation of impervious layer beneath the plough layer (Basak et al., 2016). A sharp decrease and increase in clay vis-à-vis silt and sand content of soils irrespective of cultivated land was noticed with depth increment (Table 2). Pronounced increase in silt and sand content in mid and sub-surface layer irrespective of cultivated soils compared to surface soil manifested the higher BD and lower porosity and saturated hydraulic conductivity due to soil compaction (Bandyopadhyay et al., 2011).

Physico-chemical properties of cultivated Soils: The $\mathrm{pH}$ of the soils under different land uses was almost neutral ranging from 7.2 to 7.4 (Table 1). There were little changes in $\mathrm{pH}$ even after continuous cultivation. The rice cultivated plots had slightly higher $\mathrm{pH}$ values than those with other land uses since submergence buffered the soils against major swings in $\mathrm{pH}$ either by taking up or releasing $\mathrm{H}^{+}$ion into the soil solution making the concentration of soil solution $\mathrm{H}^{+}$ion more constant resulting into a stable $\mathrm{pH}$ near to neutrality (Malhi et al., 2011). Electrical conductivity was very low ranged from $0.14-0.18 \mathrm{dS} \mathrm{m}^{-1}$. The OC content of the soils varied from 3.9 to $4.9 \mathrm{~g} \mathrm{~kg}^{-1}$ with a mean value of $4.4 \mathrm{~g} \mathrm{~kg}^{-1}$. The lowest value $\left(3.9 \mathrm{~g} \mathrm{~kg}^{-1}\right)$ was recorded with soil under arhar whereas the highest value was associated with soil under rice crop $\left(4.9 \mathrm{~g} \mathrm{~kg}^{-1}\right)$. Submergence along with algal biomass infestation with rhizodeposition under wet land rice cultivation results more organic $\mathrm{C}$ in soil compared to other aerobic cultivation (Mandal, 2011). Rice adopted soil had the higher CEC compared to other. This was possibly due to the fact that higher clay and organic matter contained different functional groups like carboxyl, phenolic and enolic contributing to the exchange capacity of the soils (Deb et al., 2016). Depth increment gradually increased the soil $\mathrm{pH}$ and decreased $\mathrm{OC}$ content and CEC in the soils irrespective of cultivated soils (Table 2) (Datta et al., 2015; Deb et al., 2016).

Physical properties of soils under forest trees: Relative proportion of sand, silt and clay ranged from 12.5 $17.1,32.8-38.0$ and $47.7-50.8 \%$ with the mean values of $14.4,35.5$ and $49.4 \%$, respectively in soils under forest trees categorized as silty clay (Table 3 ). Soils under Jhau plantation had low bulk density due to presence of relatively less amount of sand (13.7\%). Soil porosity varied significantly. The highest value was associated with Sagun (46.2\%) followed by Sirish 
Tapan Kumar Kisku et al. / J. Appl. \& Nat. Sci. 9 (3): 1482 -1488 (2017)

Table 5. Coefficient of correlation $(r)$ amongst hydraulic conductivity with different physical parameter.

\begin{tabular}{lll}
\hline Crop vegetation & & \\
\hline Soil parameter & Cation exchange capacity & Bulk density \\
Hydraulic conductivity & $-0.55^{*}$ & $-0.53^{*}$ \\
\hline Forest land & & \\
\hline Soil parameter & Sand & Clay \\
Hydraulic conductivity & $0.68^{*}$ & $-0.71^{* *}$ \\
\hline
\end{tabular}

*and ** significant at 5 and $1 \%$ level

Table 6. Principal component matrix for predicting variance of hydraulic conductivity.

\begin{tabular}{lccc}
\hline Variable & $\mathbf{P C}_{\mathbf{1}}$ & $\mathbf{P C}_{\mathbf{2}}$ & $\mathbf{P C}_{\mathbf{3}}$ \\
\hline Eighen value & 5.54 & 3.65 & 2.54 \\
Percent of Variance & 42.63 & 28.11 & 19.52 \\
Cumulative percent & 42.63 & 70.74 & 90.26 \\
Eighen vectors & & & $\mathbf{0 . 8 0}$ \\
Bulk density & -0.45 & $\mathbf{- 0 . 3 0}$ & -0.54 \\
pH & -0.18 & $\mathbf{- 0 . 8 2}$ & 0.42 \\
Electrical conductivity & -0.89 & $\mathbf{- 0 . 1 2}$ & 0.68 \\
Organic carbon & $\mathbf{0 . 6 5}$ & 0.05 & 00 \\
Hydraulic conductivity & $\mathbf{0 . 8 7}$ & $\mathbf{- 0 . 2 3}$ & -0.54 \\
Porosity & $\mathbf{0 . 7 0}$ & 0.30 & 0.43 \\
Cation exchange capacity & -0.07 & 0.87 & 0.16 \\
Sand & $\mathbf{0 . 1 8}$ & $\mathbf{- 0 . 9 6}$ & -0.50 \\
Silt & $\mathbf{0 . 2 5}$ & 0.43 & 0 \\
Clay & -0.29 & $\mathbf{0 . 9 3}$ & \\
\hline
\end{tabular}

Bold values indicate highly weighted variables for the respective principal components (PC)

(43.7\%), Jhau (41.7\%), Sissoo (40.7\%) and Lamboo $(31.7 \%)$ in decreasing order. The highest porosity in soils under Sagun plantation was possibly due to voluminous leaf litter deposition. Bulk density typically increased along depth in studied soils irrespective of plantation since sub-surface layers have reduced organic matter, aggregation, and root penetration compared to surface layers and therefore, contain less pore space (Datta et al., 2015; USDA, 2008). The saturated hydraulic conductivity of the soils under tree plantation was found to be more or less similar with a mean value of $0.84 \mathrm{~cm} \mathrm{hr}^{-1}$. However, soil under Sagun tree showed greater hydraulic conductivity $\left(1.10 \mathrm{~cm} \mathrm{~h}^{-1}\right)$ followed by Sirish, Jhau, Lamboo and Sissoo with $0.86,0.79,0.74$ and $0.72 \mathrm{~cm} \mathrm{~h}^{-1}$, respectively. A decreasing bulk density and increasing soil porosity favoured continuous macropores thereby increasing hydraulic conductivity (Bormann and Klaassen, 2003).

Physico-chemical properties of soils under forest trees: Results showed that the $\mathrm{pH}$ of the soils under different tree plantations were slightly acidic in nature (Table 3). Its values differed when estimated in soilwater (6.3-6.8, mean 6.5) suspensions. Variations in acidity among the soils were due to production of organic acids by decomposition of leaf litter and their difference in biochemical composition (Datta et al., 2015). Soil under Jhau plantation recorded the highest value $\left(6.8 \mathrm{~g} \mathrm{~kg}^{-1}\right)$ of OC followed by Sagun and Sissoo (5.8 $\mathrm{g} \mathrm{kg}^{-1}$ ), Lamboo (5.7 $\mathrm{g} \mathrm{kg}^{-1}$ ) and Sirish (5.6 g $\left.\mathrm{kg}^{-1}\right)$. The highest $\mathrm{OC}$ was observed in Jhau plantation which might be due to less sand content and higher CEC. Soil belongs to identical parent material and cli- mate conditions, OC content of it significantly influenced by soil texture and soil cation exchange capacity (Conforti et al., 2016). The highest OC concentrations were observed in the surface soil irrespective of type of tree plantation and gradually decreased from the surface to mid-surface to sub-surface layers (Table 4). The decreased OC concentrations in subsurface layers might be due to reduction in input of surface litter. Decreasing input from surface litter and decreasing root density with increasing depth contributed to the lower OC in both mid and sub-surface compared with surface soil (Schenk, 2008; Deb et al., 2016).

There was significant negative correlation between the CEC $(r=-0.55, p<0.05)$ and BD $(r=-0.53, p<0.05)$ of soils under crop cultivation with hydraulic conductivity (Table 5). Whereas, hydraulic conductivity had significant and positive correlation with sand $(r=0.68$, $p<0.01)$ while it had significant and negative correlation with clay $(r=-0.71, p<0.05)$. This indicated that increase in sand content increased the hydraulic conductivity and the reduction of clay percent of the forest soil did contribute the enhancement of hydraulic conductivity of the soil. Such finding was also reported by Nayak et al. (2004).

Total multivariate mean data of all three systems measured at three different depths of all parameters under study were subjected to principal component analysis (PCA) for comparing the treatment combinations (sequence) like depth vs. system. Total three components (PC) extracted explaining $90.3 \%$ of total variance with reference to eighen value more than 1 . First PC explained $42.6 \%$ and organic C, hydraulic 
conductivity, porosity, sand and silt were highly positively loaded factors (Table 6). Second PC explained $28.1 \%$ of total variance here hydraulic conductivity accompanied with BD, electrical conductivity and sand were highly negatively loaded variables (Fig. 1).

\section{Conclusion}

Soil hydraulic conductivity was greater under cabbage $\left(2.8 \mathrm{~cm} \mathrm{hr}^{-1}\right)$ and sagun tree $\left(1.10 \mathrm{~cm} \mathrm{~h}^{-1}\right)$ among the cultivated and forest land uses, respectively. Hydraulic conductivity showed positive and negative correlation with the sand $(r=-0.68 ; P>0.05)$ and clay $(\mathrm{r}=-0.71$; $P>0.05)$ fraction of the soil, respectively. Soil under Jhau plantation recorded the highest value $\left(6.8 \mathrm{~g} \mathrm{~kg}^{-1}\right)$ of OC due to soil texture and soil cation exchange capacity. Principal component analysis concluded that clay and sand content and bulk density are the key parameters identified for forecasting the large variation of hydraulic conductivity under different land uses.

\section{REFERENCES}

Assouline, S. and Or, D. (2013). Conceptual and parametric representation of soil hydraulic properties: a review. Vadose Zone J., 12: 1-20. http://dx.doi.org/10.2136/ vzj2013.07.0121.

Bandyopadhyay, P. K., Saha, S. and Mallick, S. (2011). Comparison of Soil Physical Properties between a Permanent Fallow and a Long-Term Rice-Wheat Cropping with Inorganic and Organic Inputs in the Humid Subtropics of Eastern India, Communications in Soil Science and Plant Analysis, 42:435-449. DOI: 10.1080/00103624.2011.542358.

Bardhan, G., Russo, D., Goldstein, D., Levy, G.J. (2016) Changes in the hydraulic properties of a clay soil under long-term irrigation with treated wastewater, Geoderma, 264A(15):1-9. doi.org/10.1016/ j.geoderma.2015.10.004.

Basak, N., Datta, A., Mitran, T., Singha Roy, S., Saha, B.,N., Biswas, S., Mandal, B. (2016) Assessing soil quality indices for sub-tropical rice-based cropping systems in India. Soil Research, 54(1): 20-29 (DOI: http:// dx.doi.org/10.1071/SR14245).

Bezabih, B., Aticho, A., Mossisa, T. and Dume, B. (2016). The effect of land management practices on soil physical and chemical properties in Gojeb Sub-river Basin of Dedo District, Southwest Ethiopia. Journal of Soil Science and Environmental Management, 7(10):154-165.

Blake, G.R and Hartge, R.R. (1986). Bulk density. In A klute (Ed.), Method of soil analysis. Part I Physical and Mineralogical Methods ( $2^{\text {nd }}$ ed.) American society of Agronomy, Medison, WI. pp.363-382.

Bormann, H. and Klaassen, K. (2008) Seasonal and land use dependent variability of soil hydraulic and soil hydrological properties of two Northern German soils, Geoderma, 145 (3-4): 295-302. DOI http:// dx.doi.org/10.1016/j.geoderma.2008.03.017.

Bouma, J., van Hoorn, J.W. and Stoffelsen, G. H. (1981). Measuring the hydraulic conductivity of soil adjacent to tile drains in a heavy clay soil in The Netherlands. Journal of Hydrology, 50: 371-381.

Bouyoucos, G. J. (1962). Hydrometer method improved for making particle size analysis of soil. Agronomy Journal,54: 464-465.

Chaudhari, S.K., Singh, R. and Kumar, A. (2010). Suitability of a hydraulic conductivity model for predicting salt effects on swelling soils. Journal of Plant Nutrition and Soil Science 173: 360-367. DOI: 10.1002/ jpln.200800075.

Chaudhari, S.K., Bardhan, G., Kumar, P., Singh, R., Mishra, A. K., Rai, P., Singh, K. and Sharma, D. K. (2015). Short-Term Tillage and Residue Management Impact on Physical Properties of a Reclaimed Sodic Soil. Journal of the Indian Society of Soil Science, 63(1): 0-38. DOI: 10.5958/09740228.2015.00005.5

Conforti, M., Lucà, F., Scarciglia, F., Matteucci, G., Buttafuoco, G. (2016b) Soil carbon stock in relation to soil properties and landscape position in a forest ecosystem of southern Italy (Calabria region). Catena, 144, 23-33., DOI. http://dx.doi.org/10.1016/j.catena.2016.04.023.

Datta, A., Basak, N., Chaudhari, S.K., and Sharma, D.K. (2015) Soil properties and organic carbon distribution under different land use in reclaimed sodic soils of North-West India. Geoderma Regional, 4: 134-146 (DOI..http://dx.doi.org/10.1016/j.geodrs.)

Deb, S., Chakraborty, S., Weindorf, D.C., Murmu, A., Banik, P., Debnath, M. K. and Choudhury, A. (2016) Dynamics of organic carbon in deep soils under rice and non-rice cropping systems, Geoderma Regional, 7(4): 388-394.http://dx.doi.org/10.1016/j.geodrs.2016.11.004.

Gomez, K. A. and Gomez, A. A. (1984). Statistical Procedures for Agricultural Research. John Wiley and Sons, New York 19-97.

Jackson, M.L. (1973). Soil Chemical Analysis. Prentice Hall of India Pvt. Ltd., New Delhi.

Malhi, S. S., Nyborg, M., Goddard, T. and Puurveen, D. (2011). Long-term tillage, straw and $\mathrm{N}$ rate effects on some chemical properties in two contrasting soil types in Western Canada. Nutrient Cycling in Agroecosystems, 90: 133-146. DOI 10.1007/s10705-010-9417-x.

Mandal, B. (2011). Soil Organic Carbon Research in India-A way forward. Journal of the Indian Society of Soil Science, 59 (Supplement): S9- S22.

Nayak, A. K., Chinchmalatpure, A. R., Rao, G. G., Khandelwal, M. K. and Nath, A. (2004). Interrelationship between water retention, transmission and some soil parameters of typical black soils of Gujarat state. $A g$ ropedology, 14(1): 38-44.

Ndiaye, B., Molenat, J., Hallair, V., Gascual, C. and Hamon, Y. (2007). Effects of agricultural practices on hydraulic properties and water movement in soils in Britanny (France). Soil and Tillage Research,93(2): 251-263.

Nelson, D. W. and Sommers, L. E. (1982). Total carbon, Organic carbon, and Organic matter. In: Methods of soil analysis. Part II (A.L. page, R.H. Millar and D.R. Keeny, ( Eds.), ASA Monograph 9, Madison, Wisconsin. pp. 539-580.

Newaj, R., Dar, S. A., Bhargava, M. K. and Yadav, R. S. (2007). Effects of management practices on growth of white siris (Albia procera), grain yield of intercrops, weed population and soil fertility changes in agrisilviculture system in semi-arid India. Indian Journal Agricultural Science, 77(7): 403-407.

Rao, N. and Mathew, P. K. (1995). Effects of exchangeable 
Tapan Kumar Kisku et al. / J. Appl. \& Nat. Sci. 9 (3): 1482 -1488 (2017)

cations on hydraulic conductivity of marine clay. Clay and clay minerals, $43(4)$ : 433-437.

Schenk, H. J. (2008). The shallowest possible water extraction profile: A null model for global root distributions. Vadose Zone J, 7: 1119 -1124.

Schollenberger, C. J. and Simon, R. H. (1945). Determination of exchange capacity and exchangeable bases in soils-ammonium acetate method. Soil Science, 59:13-24.
USDA (2008). Natural Resources Conservation Service. Soil quality indicators. http://soils.usda.gov/sqi/assessment/ files/bulk_density_sq_physical_indicator_sheet.pdf.

Yuksek, T., Kurdoglu, O. and Yuksek, F. (2010). The effects of land use changes and management types on surface soil properties in kafkasor protected area in Artvin, Turkey. Land Degradation and Development 21: 582590. 